5-1-1989

\title{
Administrative Procedure and the Internal Revenue Service: Delimiting the Substantial Understatement Penalty
}

Peter A. Appel

University of Georgia, appel@uga.edu

b bepress SSRN

\section{Repository Citation}

Peter A. Appel, Administrative Procedure and the Internal Revenue Service: Delimiting the Substantial Understatement Penalty (1989),

Available at: https://digitalcommons.law.uga.edu/fac_artchop/861

This Article is brought to you for free and open access by the Faculty Scholarship at Digital Commons @ University of Georgia School of Law. It has been accepted for inclusion in Scholarly Works by an authorized administrator of Digital Commons @ University of Georgia School of Law. Please share how you have benefited from this access For more information, please contact tstriepe@uga.edu. 
Notes

\title{
Administrative Procedure and the Internal Revenue Service: Delimiting the Substantial Understatement Penalty
}

\author{
Peter A. Appel
}

In the early 1980's, Congress faced the mounting problems of tax shelters and other forms of tax avoidance. It responded by passing a series of laws. ${ }^{1}$ One of these provisions, section 6661 of the Internal Revenue Code, penalizes "substantial understatement" of tax liability. ${ }^{2}$ While section 6661 may appear to be a typical, innocuous tax code provision, close examination reveals that the substantial understatement penalty threatens to expand quietly the power of the Internal Revenue Service (IRS) over taxpayers, violating the spirit of the Administrative Procedure Act (APA) in the process.

In exercising their rulemaking power, agencies must generally observe the notice and comment proceedings mandated by the APA in 5 U.S.C. $\S$ $553 .^{3}$ There are, however, a number of exceptions to the APA's notice and comment requirement," one of the most important of which covers "inter-

1. Tax Reform Act of 1986, Pub. L. No. 99-514, 100 Stat. 2085 (codified in scattered sections of 26 U.S.G.); Omnibus Budget Reconciliation Act of 1986, Pub. L. No. 99-509, 100 Stat. 1874 (codified in scattered sections of 26 U.S.C.); Tax Equity and Fiscal Responsibility Act of 1982, Pub. L. No. 97-248, 96 Stat. 324 (codified in scattered sections of 26 U.S.C.).

Congress recently amended the 1986 Code in the Technical and Miscellaneous Revenue Act of 1988, Pub. L. No. 100-647, 1988 U.S. Code Cong. \& ADmIn. News (102 Stat.) 3342 (to be codified in scattered sections of 26 U.S.C.). Among the many new provisions was subtitle J, entitled the Omnibus Taxpayer Bill of Rights. Id. $\$ \S 6226-6247,102$ Stat. at $3730-52$.

2. I.R.C. $\$ 6661$ (1986).

3. 5 U.S.C. $\S 553(1982)$.

4. 5 U.S.C. $\$$ 553(b) (1982). 
pretative rules." In theory, interpretative rules represent only policy determinations or litigating positions for the agency. In practice, however, courts often defer to the agency's decision and give it the force of law. ${ }^{6}$

Each year the IRS issues a vast number of rulings standardizing taxpayer liability to the government, including Treasury regulations, revenue rulings, and revenue procedures. Although Treasury regulations are usually promulgated after notice and comment, revenue rulings and revenue procedures-which courts generally characterize as interpretative-are not subjected to that procedure. Through its interpretations of section 6661, the IRS has, in effect, declared that its interpretative pronouncements represent binding law for taxpayers and their counsel, and disobedience will result in penalties. ${ }^{7}$ Because of this provision, the possibility now exists that the interpretative rules of the IRS will have effects beyond their content that dictates substantive tax liability. ${ }^{8}$ Such an outcome threatens to undermine administrative law principles.

Section I of this Note explores the background of section 6661 and its interpretation by the Department of Treasury. Section II explains the first problem with the Regulation, ${ }^{9}$ namely the compulsion of taxpayer deference to IRS interpretative rules. Section III discusses how Treasury's interpretation of 6661 limits the authorities that taxpayers may cite to avoid the penalty, excluding some authorities that taxpayers may refer to when they are trying to escape substantive tax liability. Section IV explores whether the proposed solutions could come from courts or whether they must emanate from Congress. The deference courts pay to adminis-

5. 5 U.S.C. 553(b)(A) (1982). Although many commentators prefer the term "interpretive," see, e.g., Asimow, Nonlegislative Rulemaking and Regulatory Reform, 1985 DUkE L.J. 381, 381 n.4, the Act uses the term "interpretative."

6. Many scholars have commented on the increased deference that courts accord interpretative rules. See, e.g., Saunders, Interpretative Rules with Legislative Effect: An Analysis and a Proposal for Public Participation, 1986 DukE L.J. 346; Note, The Substantial Impact Test: Victim of the Fallout from Vermont Yankee?, 53 GEO. WASH. L. REv. 118 (1984) [hereinafter Note, Substantial Impact Test]. Other commentators have noted the problem of interpretative rules, both in the context of taxation and more generally, and have suggested different alternatives. See Asimow, supra note 5 (noting problems with pre-adoption notice and comment, and suggesting use of notice and comment after adopting interpretative rule); Asimow, Public Participation in the Adoption of Interpretive Rules and Policy Statements, 75 MICH. L. REv. 520 (1977) (suggesting post-adoption notice and comment); Bonfield, Some Tentative Thoughts on Public Participation in the Making of Interpretative Rules and General Statements of Policy Under the A.P.A., 23 ADMIN. L. REv. 101 (1971) (suggesting further study of problem); Koch, Public Procedures for the Promulgation of Interpretative Rules and General Statements of Policy, 64 GEo. L.J. 1047 (1976) (suggesting repeal of APA exemption for interpretative rules or development by courts of substantive impact doctrine); Saunders, supra (courts should apply combination of substantial impact test and agency intention to find interpretative rules); Comment, A Functional Approach to the Applicability of Section 553 of the Administrative Procedure Act to Agency Statements of Policy, 43 U. CHI. L. REv. 430 (1976) (advocating substantial impact doctrine); Note, Revenue Rulings and the Federal Administrative Procedure Act, 1975 WIS. L. REv. 1135 (advising practitioners).

7. Treas. Reg. $\S 1.6661-3$ (1985).

8. Throughout this Note, the phrase "substantive liability" will refer to the amount of tax that a taxpayer should declare on her return. See I.R.C. $\$ 6661(b)(2)$ (1986). Section 6661 imposes a penalty in addition to any substantive liability.

9. Treas. Reg. $\S 1.6661-3$ (1985). 
trative agencies suggests that judicial adoption of this Note's proposed reading might be precluded. This conclusion might provide impetus to Congress to revisit not only the words of section 6661 but also the issue of judicial deference to administrative agencies generally. ${ }^{10}$

\section{Background: Taxing Systems and the Tax Penalty}

Section 6661 is part of a larger system of penalizing those taxpayers who misstate or otherwise fail to pay their taxes. By referring to "authority," section 6661 alludes to a large body of administrative pronouncements that the IRS issues yearly.

\section{A. The Tax Avoidance Problem and Congressional Responses}

Taxpayers in the United States often play the "audit lottery," gambling that the Service will not catch questionable positions on their returns because there are too many returns for the IRS to review each one carefully. ${ }^{11}$ In the late 1970's, the potential costs of taking an aggressive position on a tax return were low. Chances were that the IRS would not audit, and even if it did, the Code had few provisions to penalize anyone but taxpayers who fraudulently evaded tax liability. Thus, if a taxpayer faced an audit and lost, she would only have to pay the back taxes plus any interest. ${ }^{12}$ Since the statutory interest rates were often below the high market interest rates of the late 1970 's, ${ }^{13}$ taxpayers had great incentive to understate their taxes.

Lawmakers had the option of responding to increasing tax avoidance in two ways: penalizing underpayment of taxes, and forbidding or limiting the substantive transactions that lead to tax avoidance. ${ }^{14}$ The United States has often pursued the latter form of control in response to the proliferation of tax shelters. ${ }^{15}$ Tax shelters have always existed, but in the late 1970's, they exploded in number.

10. Many of the arguments made in this Note apply to other government agencies as well. This Note focuses on the IRS because it poses unique problems for the scholar of administrative law. Among other things, Treas. Reg. $\S 1.6661-3$ (1985) is unusual because it requires individuals to defer to interpretative rules, and threatens imposition of criminal-like fines for non-compliance.

11. See 1 S. ReP. No. 494, 97th Cong., 2d Sess. 272-73, reprinted in 1982 U.S. Code Cong. \& ADMin. News 781, 1019-20 [hereinafter TEFRA SENATE REPORT]. Rather than figuring out every citizen's taxes, the IRS relies heavily on accurate self-assessment for the bulk of returns. IRS, INTERNal Revenue Manual $\S$ (11)911 (1979), reprinted in 6 Internal Revenue Manual-Administration (CCH) 35,951; see also 1985 IRS Comm'r \& ChIEF Counsel ANN. ReP. 12, $60(1.31 \%$ of all individual returns audited).

12. TEFRA Senate Report, supra note 11 , at 272-73, 1982 U.S. Code Cong. \& Admin. NEwS at 1019-20.

13. M. Graetz, Federal Income Taxation: Principles and Policies 98 (2d ed. 1988).

14. The United States has taken both approaches; the 1982 Amendments created more penalties, and the 1986 Code eliminated many of the substantive transactions that allowed tax avoidance. See infra notes $16-18$ \& note 118 .

15. Tax shelters are transactions that have little or no real economic benefit for the investor, until she accounts for tax savings. See generally Cooper, The Taming of the Shrewd: Identifying and Controlling Income Tax Avoidance, 85 CoLuM. L. REv. 657 (1985) (outlining main strategies of 
In 1982, Congress enacted the Tax Equity and Fiscal Responsibility Act (TEFRA), ${ }^{16}$ and included section $6661^{17}$ as a partial response to these problems. ${ }^{18}$ Section 6661 imposes a penalty of twenty-five percent ${ }^{19}$ on any "substantial understatement" of taxes. ${ }^{20}$ Taxpayers may avoid the penalty if they adequately disclose their position" or if they have "substantial authority" for the tax treatment of any item on their return, even if their position is ultimately rejected. ${ }^{22}$ If the item involves a tax shelter, ${ }^{23}$ the taxpayer must meet the higher standard"2 of showing that she "reasonably believed that the tax treatment of such item . . . was more likely than not the proper treatment.".25

Section 6661 differentiates between a taxpayer's substantive liability and that taxpayer's substantial understatement liability, i.e. whether the taxpayer's failure to assess her substantive liability correctly should lead

income tax shelters).

16. Pub. L. No. $97-248,96$ Stat. 324 (1982) (codified in scattered sections of 26 U.S.C.).

17. TEFRA § 323, Pub. L. No. 97-248, 96 Stat. at 613-15.

18. TEFRA included other penalties. TEFRA $\S 318$, Pub. L. No. $97-248$, 96 Stat. at 610 (codified at I.R.C. $\S 6651(1986)$ ) (penalty for late payment of taxes if failure to pay stems from willful neglect and not reasonable cause); id. $\S 315,96$ Stat. at 605-07 (codified at I.R.C. $\$ 6652$ (1986)) (duty to report certain information, e.g. income from tips; I.R.C. $\S 6652$ (b) (1986)); id. $\$ 325,96$ Stat. at 616-17 (codified at I.R.C. $\S 6653(\mathrm{a})(2)$-(b) (1986)) (increased penalty for fraudulent or negligent tax avoidance); $i d$. $\S 316,96$ Stat. at 607 (codified at I.R.C. $\S 6676$ (1986)) (penalizing those who fail to report identification number on their returns); id. $\$ 320,96$ Stat. at $611-12$ (codified at I.R.C. $\$ 6700$ (1986)) (penalizing promoters of abusive tax shelters); id. $\$ 324,96$ Stat. at $615-16$ (codified at I.R.C. $\$ 6701$ (1986)) (fine for aiding and abetting substantial understatement).

The Code also makes borrowing from the government (i.e., understating tax liability because statutory interest rates applied to unpaid taxes are favorable) more expensive. Section 6621 establishes a two-tiered interest rate structure. Compare I.R.C. $\S 6621$ (a)(1) (1986) (interest rate for underpayments to government) with I.R.C. $\$ 6621$ (a)(2) (1986) (overpayments of tax to government, as defined in I.R.C. $\$ 6611$ (1986) earn less interest than that charged for underpayments to government). The underpayment rate increases for substantial underpayments attributed to certain tax-motivated transactions, I.R.C. $\$ 6621(\mathrm{c})(1986)$, and interest compounds daily, I.R.C. $\$ 6622$ (1986).

19. While the original penalty was $10 \%$, TEFRA $\S 323,96$ Stat. at $613-14$, Congress simultaneously passed one law raising the penalty to $20 \%$ and one raising it to $25 \%$. The Tax Court has held that the higher penalty applies. See Pallottini v. Commissioner, 90 T.C. 498 (1988).

20. I.R.C. $\$ 6661(\mathrm{a})$ (1986). I.R.C. $\$ 6661$ (b)(2)(A) (1986) defines "understatement" as the amount of tax that the taxpayer should have reported minus the amount that the taxpayer did report. I.R.C. $\$ 6661(b)(1)(1986)$ defines "substantial understatement" as the greater of "10 percent of the tax required to be shown on the return for the taxable year" and a set amount $(\$ 5,000$ for individuals and $\$ 10,000$ for corporations).

21. I.R.C. $\$ 6661(\mathrm{~b})(2)(B)(\mathrm{i})(1986)$. The IRS defines "adequate disclosure" as a statement on a Form 8275 or similar attachment to the taxpayer's return. Treas. Reg. $\$ 1.6661-4(b)(1)(1985)$. In Schirmer v. Commissioner, 89 T.C. 277 (1987), the Tax Court held that a taxpayer need only provide enough information to identify the potential controversy, but must do more than simply file a return. Id. at 285-86. The Secretary of the Treasury may waive the understatement penalty "on a showing by the taxpayer that there was reasonable cause for the understatement . . and that the taxpayer acted in good faith;" this applies both to regular transactions and tax shelters. 1.R.C. $\S$ 6661(c) (1986). A reviewing court will apply an abuse of discretion standard to denials of the waiver. Estate of Goodwin v. Commissioner, 55 T.C.M. (CCH) 702 (1988).

22. I.R.C. $\$ 6661(\mathrm{~b})(2)(B)(i)(1986)$.

23. Id. $\$ 6661$ (b)(2)(C)(ii) defines tax shelter as any scheme, plan, or arrangement the purpose of which "is the avoidance or evasion of Federal income tax."

24. I.R.C. $\S 6661(\mathrm{~b})(2)(\mathrm{C})(1986)$; see Gjesteby v. Commissioner, 54 T.C.M. (CCH) 1364, 1375 (1987) (standard for authority more stringent if tax shelter involved).

25. Id. $\S 6661(\mathrm{~b})(2)(\mathrm{C})(\mathrm{i})(\mathrm{II})$. Adequate disclosure, moreover, is no defense to the penalty in tax shelter cases. $I d$. $\$ 6661(\mathrm{~b})(2)(\mathrm{C})(\mathrm{i})(\mathrm{I})$. 
to the penalty. Theoretically, three types of substantial understatement cases could arise. First, there could be cases in which the Commissioner loses on the substantive tax issue; in those cases, no penalty for substantial understatement can be imposed. ${ }^{26}$ Second, there could be cases in which the taxpayer owes both the tax and the penalty. ${ }^{27}$ Third, there could be cases in which the taxpayer owes the tax but, because she had substantial authority for her position, no penalty should be applied. ${ }^{28}$ This Note is concerned primarily with the third category.

\section{B. A Taxonomy of Modern Internal Revenue Service Pronouncements}

Before delving further into this last category of cases, one needs to know how the United States helps its citizens determine how much tax they owe. Section 7805 of the Internal Revenue Code authorizes the Secretary of the Treasury to issue "all needful rules and regulations for the enforcement" of the Gode. ${ }^{28}$ In addition, the Service communicates its own position on different issues to taxpayers in a number of different ways. ${ }^{30}$

The Treasury Department exercises its section 7805 authority most directly through Treasury regulations, which are codified as Title 26 of the Code of Federal Regulations. Treasury usually issues these after notice and comment, and often has hearings on the substance of the proposed regulations. Courts will enforce Treasury regulations unless they clearly conflict with the language or intent of the Internal Revenue Code, are unreasonable, or exceed the scope of the Secretary's power. ${ }^{31}$ Because the

26. See, e.g., Seebold v. Commissioner, 55 T.C.M. (CCH) 723 (1988); Feldman v. Commissioner, 55 T.C.M. (CCH) 450 (1988).

27. See, e.g., Rothstein v. Commissioner, 90 T.C. 488 (1988); Estate of Goodwin v. Commissioner, 55 T.C.M. (CCH) 702 (1988); Farah v. Commissioner, 53 T.C.M. (CCH) 1282 (1987).

28. Extensive research by this author has not revealed such a case. Many reasons might explain this gap. First, the Treasury regulations under $\S 6661$ were promulgated only in 1985; many of the most recent cases coming from the Tax Court involve transactions that antedate the regulations. See, e.g., Gjesteby v. Commissioner, 54 T.C.M. (CCH) 1364 (1987) (1982 transactions challenged). Second, most tax cases do not reach the courts; a substantial portion are settled. 1985 IRS CoMM'R \& Chief Counsel ANN. ReP. 34, 68 (84.9\% of cases not docketed with Tax Court and $89.6 \%$ of docketed cases were settled). Section 6661 and Treas. Reg. \$ 1.6661 (1985) provide the Service with more leverage in settlement negotiations because it can threaten to invoke the penalty to discourage a taxpayer's challenge to a revenue ruling or revenue procedure. See also infra note 53 (public tends to accept interpretative rulings, like revenue rulings, as determinative).

29. I.R.C. $\S 7805$ (a) (1986). In fact, Internal Revenue Service employees draft the regulations, which the Secretary usually approves; see Treas. Reg. $\S 301.7805-1$ (1988). I.R.C. § 7805(a) (1986) contains an exception for certain regulations which the Code specifically requires administrators in the Service to issue. Congress recently amended $\S 7805$ to require the Secretary to submit all temporary regulations as proposed rules; it also limits the effect of proposed regulations to three years. Technical and Miscellaneous Revenue Act of 1988, Pub. L. No. 100-647 § 6232, 1988 U.S. CoDE ConG. \& ADmin. News (102 Stat.) 3734-35 (to be codified at I.R.C. § 7805(e)-(f)).

30. The bulk of the material in this Section is derived from four sources: 4 B. BITTKER, FeDERAL Taxation of Income, Estates and Gifts (1981); M. Graetz, supra note 13, at 70-75; G. Richmond, Federal Tax Research (2d ed. 1985); and Rogovin, The Four R's: Regulations, Rulings, Reliance and Retroactivity, 43 TAXEs 756 (1965).

31. See, e.g., United States v. Cartwright, 411 U.S. 546, 557 (1973) (Treasury regulation stricken because unreasonable); Helvering v. R.J. Reynolds Tobacco Co., 306 U.S. 110 (1939) (regulation issued in excess of Secretary's authority void); Koshland v. Helvering, 298 U.S. 441, 447 (1936) 
Secretary usually follows the APA's notice and comment requirement, ${ }^{32}$ and indeed sometimes exceeds it by offering public hearings, Treasury regulations are not central to the argument of this Note. ${ }^{33}$

The IRS issues revenue rulings ${ }^{34}$ and revenue procedures. ${ }^{36}$ These do not undergo a notice and comment period, but still act as binding rules on taxpayers. ${ }^{38}$ The Commissioner has no authority in the Code to issue revenue rulings other than his general authority derived from the Secretary of the Treasury's section 7805 power.

The IRS also issues less formal communications. The most frequent are the letter ruling and private determination, in which the Service's National Office or District Directors respectively answer questions from taxpayers about the tax implications of particular transactions. ${ }^{37}$ The Service has only recently begun to publish private determinations but these rul-

(regulation contrary to plain meaning of Code void).

32. See 5 U.S.C. $\S 553$ (1982) (agencies must announce rules prior to promulgation and allow public to make written comments).

33. But see, e.g., Miscellaneous Federal Tax Matters, 52 Fed. Reg. 2724-25 (1987) (withdrawal of notices of proposed rulemaking because some can be accomplished by interpretative rules). The Treasury Department thus recognizes that it might accomplish its ends with less cumbersome procedures than those mandated in the APA.

34. See Rev. Proc. 89-1 § 4.07, 1989-1 I.R.B. 8, 11 (defining revenue rulings and their effect). Sometimes the Commissioner establishes law through revenue rulings. In Industrial Valley Bank \& Trust v. Commissioner, 66 T.C. 272 (1976), the Tax Court noted that "in the field of bad debt reserves of banks, the applicable rules appear to have been customarily laid down by revenue ruling rather than by regulation." Id. at 280; see also 4 B. BrTTKER, supra note 30 , I 110.5.4, at 110-46 to -48. "As considered expressions of the IRS' views, revenue rulings and regulations differ more in degree than in kind, and it is not clear that a sharp distinction in their weight is warranted." Id. at 110-47.

35. A "revenue procedure" is an official statement of a procedure published in the Bulletin that either affects the rights or duties of taxpayers or other members of the public under the Internal Revenue Code and related statutes and regulations, or, although not necessarily affecting the rights and duties of the public, should be a matter of public knowledge.

Rev. Proc. 86-15 § 3.02, 1986-1 C.B. 544, 544. Compare id. with Cabais v. Egger, 690 F.2d 234, 238 (D.C. Cir. 1982) (creation of new rights or duties distinguishes a legislative rule).

36. See, e.g., Rev. Rul. 89-1, 1989-1 I.R.B. 6 (setting applicable federal interest rate for purposes of I.R.C. § 1274(d) (1986)). Section 1274(d) authorizes the Secretary to promulgate such rules, but this seems to authorize the issuance of a legislative regulation, i.e. one issued with notice and comment. "Several courts have indicated that, in doubtful cases, rules made pursuant to specific rulemaking powers are more likely to be treated as legislative than are rules made pursuant to general rulemaking powers." Asimow, supra note 5, at 395.

The IRS has also announced substantive policy in revenue procedures. For the example of depreciation schedules, see Rev. Proc. 62-21, 1962-2 C.B. 418 (announcing 1962 depreciation allowance), revoked by Rev. Proc. 72-10, 1972-1 C.B. 721, superseded by Rev. Proc. 77-10, 1977-1 C.B. 548, superseded by Rev. Proc. 83-35, 1983-1 C.B. 745, obsoleted by Rev. Proc. 87-56, 1987-2 C.B. 674, clarified and modified by Rev. Proc 88-22, 1988-18 I.R.B. 38.

37. See Rev. Proc. 89-1 § 8, 1989-1 I.R.B. 8, 13 (describing procedures for obtaining private rulings and their effect). Letter rulings and determination letters have substantially the same effect. 
ings cannot be relied on as precedent. ${ }^{38}$ The Service routinely issues a list of subjects upon which it will not issue private determinations. ${ }^{39}$

In addition to pronouncements issued to taxpayers, the IRS also announces its litigation position for future disputes. This policy, called nonacquiescence, is pursued to indicate the IRS's refusal to adhere to the precedential effect of a case. ${ }^{10}$ Sometimes these decisions are announced in the form of Actions on Decisions; at other times, the Service will announce its challenge to a decision through a revenue ruling. ${ }^{41}$ While it usually will challenge only the rulings of the Tax Court, the Service will sometimes refuse to recognize a decision of a court of appeals. ${ }^{42}$ The IRS has never directly challenged a ruling of the Supreme Court.

The Service also announces policy in other forms including General Counsel Memoranda, ${ }^{43}$ Technical Advice Memoranda, ${ }^{44}$ Technical Mem-

38. I.R.C. $\S 6110(j)(3)$ (1986), which governs the rulings program, prohibits the use of written determinations as precedent. Despite this prohibition, some courts have used letter rulings as a guide to how the Service has treated taxpayers in similar situations. E.g., Rowan Cos. v. United States, 452 U.S. 247, 261 n.17 (1982); Xerox Corp. v. United States, 656 F.2d 659, 660 \& n.3 (Ct. Cl. 1981); Niles v. United States, 520 F. Supp. 808, 814 \& n.2 (N.D. Cal. 1981). The Service itself encourages the use of private letter rulings as a guide to research. IRS, REvenue RuLing HaNDBook $\S$ 221(1)(a) (1979), reprinted in 6 Internal Revenue Manual-Administration (CCH) 35,995, at 35,995-13 to -14; see also Rogovin, supra note 30, at 765-66 (private rulings often source of revenue rulings).

39. See Rev. Proc. 89-3, 1989-1 1.R.B. 29. For a good discussion of the reasons for this policy, see Note, The Availability and Reviewability of Rulings of the Internal Revenue Service, 113 U. PA. L. REv. 81, 86-94 (1964).

40. See Rogovin, supra note 30, at 771-72 (describing history of policy). If the Commissioner decides not to acquiesce, he still must follow the case's holding with respect to the taxpayer involved in the litigation. Even where the Commissioner does acquiesce, he may later decide to relitigate, thus making reliance by taxpayers on acquiescence a risky business. See Dixon v. United States, 381 U.S. 68 (1965) (Commissioner may reverse earlier decision to acquiesce); see also Carter, The Commissioner's Nonacquiescence: A Case for a National Court of Tax Appeals, 59 TEMPLE L.Q. 879 (1986) (suggesting national court of tax appeals to inhibit use of nonacquiescence); Rodgers, The Commissioner "Does Not Acquiesce", 59 NeB. L. REv. 1001 (1980) (same); Note, The Commissioner's Nonacquiescence, 40 S. CAL. L. REv. 550 (1967) (suggesting that Commissioner publish all acquiescences, a policy now followed). See generally Estreicher \& Revesz, Nonacquiescence by Federal Administrative Agencies, 98 YALE L.J. 679 (1989) (examining practice of nonacquiescence in federal agencies); Maranville, Nonacquiescence: Outlaw Agencies, Imperial Courts, and the Perils of Pluralism, 39 VAND. L. REv. 476 (1986) (same).

41. See, e.g., Rev. Rul. 75-83, 1975-1 G.B. 112, in which the Service concluded that the Eighth Circuit decided Wright v. United States, 482 F.2d 600 (8th Cir. 1973), incorrectly, and that therefore the IRS would continue to dispute the court's position.

42. See Rogovin, supra note 30 , at $771-72$. Circuit court rulings only establish precedent for that circuit; therefore one circuit court cannot make tax law for the nation. See Carter, supra note 40, at 883-85; Rodgers, supra note 40 , at 1004.

Under Treas. Reg. 1.6661-3(b)(4)(ii) (1985), taxpayers may cite court cases from any jurisdiction as substantial authority; the circuit to which they may appeal is not taken into account. However, "there is substantial authority for the tax treatment of an item if the treatment is supported by controlling precedent of a United States Court of Appeals to which the taxpayer has a right of appeal with respect to the item." Id.

43. A General Counsel Memorandum (GCM) is a memorandum from the Office of the Chief Counsel to the Assistant Commissioner (Technical) in response to a formal question. GCM's help the Assistant Commissioner (Technical) formulate new revenue rulings, private letter determinations, or Technical Advice Memoranda. See Taxation with Representation Fund v. IRS, 646 F.2d 666, 669-71 (D.C. Cir. 1981). Courts sometimes use GCM's as an indicator of IRS policy. See, e.g., Automobile Club of Michigan v. Commissioner, 353 U.S. 180, 185-86 \& n.12 (citing GCM as beginning of reversal of policy allowing tax exemption for automobile clubs), reh'g denied, 353 U.S. 989 (1957); 
oranda, ${ }^{45}$ and remarks by the Secretary of Treasury. ${ }^{46}$ Courts have cited all of the pronouncements described in this Section as internal revenue policy, but the regulations do not permit taxpayers to cite all of them as authority against the Service. ${ }^{47}$

\section{Compelled TaXpayer Deference to IRS INTERPRetative RULES}

The Secretary of the Treasury has issued six regulations under section 6661. One of these, Treasury Regulation 1.6661-3, defines "authority" to include certain interpretative rules. The distinction between interpretative and legislative rules is not clear but it has some significance in administrative law. Theoretically, interpretative rules should have less effect than legislative rules, but courts tend to defer to them equally. ${ }^{48}$ Because of this equal deference, if courts enforce Regulation 1.6661-3 as written, they will compel taxpayers to defer to IRS pronouncements that are supposed to represent no more than the Service's own interpretation.

\section{A. The Distinction Between Legislative and Interpretative Rules}

\section{The History of the Distinction}

In 1939, President Roosevelt directed Attorney General Murphy to appoint a special committee and study administrative procedure in the various federal agencies. The number of agencies and their powers had risen greatly in the New Deal era, and the jumble of idiosyncratic agency procedure, which then comprised the bulk of administrative law, accomplished little except to confuse citizens, conceal agency activity from public scrutiny, and hide regulations from the government itself. The Attorney

see also Fribourg Navigation Co. v. Commissioner, 383 U.S. 272, 279-80 \& n.5 (1966) (GCM's part of array of authority that creates consistent administrative interpretation to which Court will defer). Taxpayers may not cite post-1955 GCM's as authority for avoiding the 6661 penalty. Treas. Reg. $\S$ 1.6661-3(b)(2) (1985).

44. Technical Advice Memoranda (TAM's) respond to questions that District Directors, in the course of making a private determination, refer to the National Office. They are within the definition of written determination, I.R.C. $\$ 6110(\mathrm{~b})(1)$ (1986), and therefore may not be cited as precedent. I.R.C. $\$ 6110(j)(3)$ (1986). In Woods Investment Co. v. Commissioner, 85 T.C. 274 (1985), the Tax Court used prior IRS interpretations of the Code expressed in a Technical Advice Memorandum to estop the Commissioner's claim of an amendment, through a new TAM, to a Treasury regulation. The court suggested that the Commissioner amend the regulation instead. Id. at $281,282 \& \mathrm{nn} .15 \&$ 16.

45. The Commissioner writes Technical Memoranda to the Assistant Secretary of Treasury (Tax Policy). See Taxation with Representation Fund v. IRS, 646 F.2d 666, 671 (D.C. Cir. 1981). The memoranda resemble a legislative history of regulations, and the Service will often rely on them for its own internal use to explain a regulation. Id. at 672. Taxpayers cannot cite technical memoranda as authority for 6661 purposes. Treas. Reg. $\$ 1.6661-3(b)(2)$ (1985).

46. Cf. Flora v. United States, 362 U.S. 145, 169 \& n.36, reh'g denied, 362 U.S. 972 (1960) (using statements by Secretary Mellon as replacement for legislative history).

47. Treas. Reg. $\S 1.6661-3(b)(2)$ (1985). But see id. $\$ 1.6661-3(b)(4)(i)$ (taxpayer permitted to use written determination as substantial authority if taxpayer is named in determination).

48. 2 K. Davis, Administrative Law Treatise $\$ \S 7.9-.11$, at 43-57 (1979). 
General's report and recommendations suggested a unified approach to administrative procedure. ${ }^{49}$ In 1946, after years of delay and debate, Congress passed the Administrative Procedure $\mathrm{Act}^{\mathrm{b0}}$ to make administrative agencies more accountable to the public.

In its final report, the Committee suggested that all administrative agencies, including the Bureau of Internal Revenue, ${ }^{\text {,1 }}$ should follow notice and comment procedures when issuing statutory rules. ${ }^{62}$ It therefore became necessary to distinguish statutory regulations from interpretative rules. The Committee recognized that the conceptual "distinction between statutory regulations and interpretative regulations is . . . blurred by the fact that the courts pay great deference to the interpretative regulations of administrative agencies, especially where these have been followed for a long time." ${ }^{\text {"3 }}$ Because interpretative regulations consequently affect private interests, the Committee examined the procedures agencies used in promulgating these rules. ${ }^{54}$

When it enacted the APA, Congress recognized that agencies promulgate interpretative rules. ${ }^{55}$ However, both the Senate and the House wanted agencies to act in good faith and use this exception and all of the other exceptions in the Act only when necessary. ${ }^{56}$ Moreover, Congress did not think that the exceptions were significant. Rather, it thought

49. U.S. Attorney Gen.'s Comm. on Admin. Procedure, Final Report of the Attorney General's Committee on Administrative Procedure 5 (1941) [hereinafter Final Report].

50. Pub. L. No. 79-404, 60 Stat. 237 (1946) (codified at 5 U.S.C. $\$ \S 551-552,553-559,701-706$ (1982)).

51. The name was changed in 1953 to Internal Revenue Service. T.D. 6038, 1953-2 C.B. 443.

52. FinAl REPORT, supra note 49 , at 167 .

53. Id. at 100; see also id. at 27 ("But the agency's interpretations are in any event of considerable importance; customarily they are accepted as determinative by the public at large, and even if they are challenged in judicial proceedings, the courts will be influenced though not concluded by the administrative opinion."). As an example of this deference, the Committee offered the treatment of the Commissioner of Internal Revenue in Brewster v. Gage, 280 U.S. 327 (1930), where the Supreme Court held that " $i t$ is the settled rule that the practical interpretation of an ambiguous or doubtful statute that has been acted upon by officials charged with its administration will not be disturbed except for weighty reasons." Id. at 336, quoted in FINAL REPORT, supra note 49, at 100. The Committee also cited Koshland v. Helvering, 298 U.S. 441 (1936), to show that the Court will reject an agency determination, even one of long standing, if that interpretation conflicts with the clear terms of a statute. Final RePORT, supra note 49, at $100 \mathrm{n} .23$ (citing Koshland).

54. Final Report, supra note 49, at 100. Although the Committee said that it would consider the processes by which interpretative rules are promulgated, the actual impact of their proposals is not clear. See id. at 195 (rulemaking portion of proposed bill with no specific provision for interpretative rules); see also id. at 226 (proposed bill in appendix to additional views of McFarland, Stason, and Vanderbilt, requiring agencies to issue interpretations as rules); 228 (under McFarland, Stason, and Vanderbilt scheme, interpretative rules issued by notice and comment).

55. See Administrative Procedure Act, Pub. L. No. 79-404, § 4(a), 60 Stat. 237 (1946) (codified at 5 U.S.C. $\$ 553(\mathrm{~b})(\mathrm{A})(1982)$ ) (exempting interpretative rules from notice and comment); see also Senate Comm. on the Judiciary, Administrative Procedure Act: Legislative History, $S$. Doc. No. 248, 79th Cong., 2d Sess. 18 (1946) [hereinafter APA Legislative History] (exception will encourage agencies to make interpretative rules); Asimow, supra note 5, at 385-88 (desirable that agencies issue interpretative rules and inform public).

56. APA LEGISLATIVE HisTORY, supra note 55, at 18-19, 200, 258. Congress did recognize that the Bureau of Internal Revenue issued interpretative rules, id. at 357, but believed that the opportunity to challenge rules and petition agencies for new rules would protect the public from arbitrary action by agencies, id. at 18 . 
agency action fell into primarily two categories, rulemaking and adjudication, ${ }^{87}$ and for both categories the Act specified procedures that would protect the public interest. Because interpretative rules would not have a statute-like impact on the public, no procedures were necessary for their promulgation. ${ }^{\text {s8 }}$

\section{The Interpretative-Legislative Distinction Today}

The distinction between legislative and interpretative rules remains obscure. The Supreme Court has never devised a test for distinguishing interpretative from legislative rules; it has only ruled on how interpretative rules should be treated by the courts. ${ }^{58}$ In theory, courts should accord great deference to legislative rules and review interpretative rules more carefully, depending on various circumstances, including which agency promulgated the rule. ${ }^{60}$ Because the Supreme Court has offered so little guidance on distinguishing the two types of rules, the courts of appeals have created most of the case law in this area.

An interpretative ruling only represents the agency's position for litigation purposes. ${ }^{61}$ Since some legislative rules interpret statutes, ${ }^{62}$ the type

57. See APA Legislative History, supra note 55, at 14 (adjudication and rulemaking are two main types of administrative justice); see also U.S. DEP'T OF JUSTICE, ATTORNEY General's MANual on the Administrative Procedure Act 14 (1947) [hereinafter Manual] (describing dichotomy between rulemaking and adjudication). As a contemporaneous interpretation of the Act, the Manual offers good insight into how the executive branch read the APA. The usual distinction between rulemaking and adjudication is that the former is prospective and the latter is retroactive. Id. This distinction does not hold up well in the case of the IRS since it may exercise its rulemaking authority retroactively; indeed, I.R.C. $\$ 7805(b)$ (1986) presumes that regulations will apply retroactively.

58. "Another reason [to exclude interpretative rules from notice and comment], which might be added, is that 'interpretative' rules-as merely interpretations of statutory provisions-are subject to plenary judicial review, whereas 'substantive' rules involve a maximum of administrative discretion." APA LEGISLATIVE HISTORY, supra note 55, at 18.

59. The Court has held that rules not promulgated in accordance with the APA do not have the binding effect of law and cannot constitute an "authorization by law." In Chrysler Corp. v. Brown, 441 U.S. 281, 315-16 (1979), Chrysler attempted to prevent the Defense Logistics Agency from releasing to Chrysler's unions equal employment opportunity reports that it had filed with the Agency. Chrysler claimed that release would violate the Trade Secrets Act, 18 U.S.C. $\$ 1905$ (1982), which requires an authorization of law before release is legal. The Court held that an interpretative rule could not constitute an "authorization of law"; this is as close as it has come to defining a functional test.

60. Batterton v. Francis, 432 U.S. 416, 425 n.9 (1977) (APA challenge to Secretary of HEW's authority to promulgate rules interpreting "unemployment" failed because Congress specifically authorized the interpretation). In Batterton, the Court established guidelines for determining whon courts should defer to agency interpretations: "Varying degrees of deference are accorded to administrative interpretations, based on such factors as the timing and consistency of the agency's position, and the nature of its expertise." Id. at 425 n.9.

61. See 2 K. Davis, supra note $48, \S 7.13$, at 59-64. But see, e.g., Merchant's Indus. Bank v. Commissioner, 475 F.2d 1063 (10th Cir. 1973). While the court acknowledged that revenue rulings "do not have the force and effect of law . . . and though entitled to consideration, they are accorded less weight than regulations," $i d$. at 1064, it proceeded to review the challenged agency action under an abuse of discretion standard rather than treating the agency's position as the position of one party, id. at 1065 .

62. See, e.g., Batterton v. Francis, 432 U.S. 416 (1977) (Secretary of HEW authorized to promulgate definition of "unemployment" for 42 U.S.C. $\$ 607$ (a) (1982)). 
of action that an agency is performing alone does not distinguish interpretative from legislative rules. In the 1970's, some courts voided purportedly interpretative rules that were found to have a substantial impact on the public. $^{83}$ Most circuits have since repudiated "substantial impact analysis," however, and instead look to a variety of factors in determining whether a rule is interpretative. ${ }^{64}$ Most notably, courts examine the agency's intent ${ }^{65}$ and the effect of the law within the statutory scheme. ${ }^{68}$ The demise of the substantial impact test came in part from changes in the Supreme Court's jurisprudence. In Vermont Yankee Nuclear Power Corp. v. Natural Resources Defense Council, the Supreme Court held that the APA sets a maximum of procedures that courts may require. ${ }^{67}$ In Vermont Yankee, the Natural Resources Defense Council (NRDC) claimed that nuclear power was so important an issue that the government should hold hearings on it; the Court nevertheless refused to grant this relief. This case has caused the circuit courts to become unwilling to impose any procedures on administrative agencies beyond those specified in section $553 .^{68}$ Thus, they have defined "interpretative rule" more broadly and exempted more rules from notice and comment. ${ }^{69}$

In the IRS context, courts have routinely found numerous IRS pronouncements, particularly revenue rulings, ${ }^{70}$ to be interpretative and

63. The leading case in this area is Pharmaceutical Mfrs. Ass'n v. Finch, 307 F. Supp. 858 (D. Del. 1970); see also Lewis-Mota v. Secretary of Labor, 469 F.2d 478 (2d Cir. 1972) (adopting substantial impact test).

64. Arrow Air v. Dole, 784 F.2d 1118, 1122-25 (D.C. Cir. 1986) (factors include: agency characterization of rule as interpretative; whether rule only reminded regulated parties of preexisting duties; whether sufficient, reasoned analysis was offered to support rule; whether rule embodied longstanding policy; whether rule created new rights or duties); General Motors Corp. v. Ruckelshaus, 742 F.2d 1561, 1564-66 (D.C. Cir. 1984) (en banc) (same factors used), cert. denied, 471 U.S. 1074 (1985); see also Note, Substantial Impact Test, supra note 6 (most circuits have explicitly repudiated substantial impact test). But see Levesque v. Block, 723 F.2d 175, 182 (1st Cir. 1983) (impact of rule is one factor to take into account in determining whether it is interpretative).

65. No court has ruled that the agency's characterization of the rule is dispositive of the issue, but many courts have held that the agency's characterization warrants judicial deference. See, e.g., Arrow Air, 784 F.2d at 1122; General Motors Corp. v. Ruckelshaus, 742 F.2d at 1565; Energy Reserves Group v. Department of Energy, 589 F.2d 1082, 1092 (Temp. Emer. Ct. App. 1978). Courts have also held that an agency claim that it has made a binding rule will trigger $\S 553$ procedures. E.g., Texaco, Inc. v. Federal Power Comm'n, 412 F.2d 740, 742 (3d Cir. 1969).

66. Courts engaging in this "legal effect" jurisprudence often look at the statute to see whether it is self-executing. See, e.g., Levesque v. Block, 723 F.2d 175, 183 (1st Cir. 1983). Some courts have used the substantial impact test together with the legal effects test: Even if the rule has legal effect and was promulgated without notice and comment, the agency committed mere "harmless error" if the rule has had no substantial impact. E.g., Energy Reserves Group, 589 F.2d at 1095 (Federal Energy Administration committed harmless error when it promulgated rule without notice and comment).

67. 435 U.S. 519 (1978). The Court said, "Agencies are free to grant additional procedural rights in the exercise of their discretion, but reviewing courts are generally not free to impose them if the agencies have not chosen to grant them." Id. at 524; see also Morton v. Ruiz, 415 U.S. 199, 232-35 (1974) (agencies may voluntarily bind themselves to greater procedural duties).

68. E.g., Cabais v. Egger, 690 F.2d 234, 237 (D.C. Cir. 1982) (Vermont Yankee prohibits court from "engraft[ing] additional procedures on agency action beyond those contemplated by the APA"); see Note, Substantial Impact Test, supra note 6.

69. See Admin. Conference of the U.S., A Guide to Federal. Agency Rulemaking 36 (1983).

70. For a definition of revenue rulings, see supra note 34. 
therefore exempt from the APA's notice and comment requirements. Under Gibson Wine Co. v. Snyder, interpretative rules are merely the Commissioner's position for the purposes of litigation, and trial courts should review the facts "de novo ab initio." "In Eastern Kentucky Welfare Rights Organization $v$. Simon, ${ }^{72}$ the court of appeals reached the merits of a challenged revenue ruling. The Welfare Rights Organization challenged Revenue Ruling 69-545, which revoked Revenue Ruling 56185. The earlier ruling required tax-exempt hospitals to provide free and low-cost services to the poor, and the later ruling lifted that requirement. The court of appeals denied relief to the plaintiffs, holding that revenue rulings fall into the "interpretative regulations" exception to the APA." The revenue ruling had "no independent binding effect and . . . courts are not bound by it unless they choose to accept it as a proper interpretation." "74 At the same time, however, the court found that the Commissioner's position represented a reasonable interpretation of the term "charitable" in the context of the Code and did not violate any explicit or implied congressional intent; therefore, the circuit court allowed the revenue ruling to stand.

Two other decisions have characterized revenue rulings as "classic examples of an interpretative ruling." ance of an amendment through revenue ruling to Treasury Regulation section 1.612-3, which concerned the advancement of royalties from mines. ${ }^{76}$ Both courts ruled that section 7805 of the Code took precedence over the APA, since the Code "reflect[ed] a specific congressional action to address a particular issue. . . . If two statutes conflict or overlap in application, the rule is that the more specific of the two takes precedence."'77

\section{B. The Deference Paid to Interpretative Rules}

When a court determines that a rule is interpretative, it holds that the rule is exempt from notice and comment. This implies, to some extent,

71. 194 F.2d 329, 332 (D.C. Cir. 1952); see infra notes 80-85 and accompanying text.

72. 506 F.2d 1278 (D.C. Cir.) (1975), vacated on other grounds, 426 U.S. 26 (1976).

73. 506 F.2d at 1291 .

74. Id.

75. Wing v. Commissioner, 81 T.C. 17,26 (1983).

76. In Wing, the court found that the Secretary had properly followed the required notice and comment for the legislative regulations, and ruled that amendments to the regulation need not undergo notice and comment. 81 T.C. at 28, 30. In Redhouse v. Commissioner, 728 F.2d 1249 (9th Cir.), cert. denied, 469 U.S. 1034 (1984), the court of appeals relied on the Tax Court's Wing decision, but found that the regulation-an amendment to a legislative rule-was interpretative and therefore need not undergo notice and comment. Id. at 1253 . The court reasoned that the revenue rulings only corrected an earlier misinterpretation of the original depletion regulations. The complete depletion regulations, as legislative rules, had to and did pass notice and comment.

77. Wing, 81 T.C. at $30 \mathrm{n} .17$ (emphasis in original); see also Redhouse, $728 \mathrm{~F} .2 \mathrm{~d}$ at 1253 (same). But see Asimow, supra note 5, at 395 (rule made pursuant to specific delegations of rulemaking power often considered legislative, not interpretative, and therefore requires notice and comment). 
that the interpretative rule will receive more stringent judicial review. ${ }^{\mathbf{7 8}}$ However, the level of review that courts in fact apply to interpretative and legislative rules has converged in recent years. ${ }^{79}$

Soon after the APA was passed, the D.C. Gircuit in Gibson Wine Co. v. Snyder ${ }^{80}$ stated that Internal Revenue rulings constitute only the Commissioner's interpretation of a section of the Treasury regulations. ${ }^{81}$ In that case, a producer of boysenberry wine challenged a revenue ruling which required manufacturers to label boysenberry wine as such, rather than as blackberry wine. The Gibson Wine Company argued that the boysenberry, being only a particularly "large and luscious newcomer"82 to the blackberry family, did not constitute a different species of fruit that necessitated special labelling. ${ }^{83}$ The Commissioner disagreed. The District Court, holding that the Commissioner's position did not bind the court, "examined the whole question on the merits de novo ab initio, made its own findings on the evidence before it, and reached its own conclusions upon the merits," agreeing with the Commissioner. ${ }^{84}$ The Court of Appeals approved of this level of review for an interpretative rule. ${ }^{85}$

Courts sometimes claim that they exercise more stringent review over interpretative rulings than those promulgated with notice and comment. ${ }^{86}$ But while no court has repudiated Gibson Wine, courts now tend to be much more deferential to agency interpretations. The rigor of judicial review reached its nadir in Chevron U.S.A. v. Natural Resources Defense Council, where the Supreme Court announced a three-part test for reviewing agency legislative rules. ${ }^{87}$ First, a court should examine the statutory language that the agency interpreted; if the agency's reading is substantially incorrect or abrogates the clear language of the statute, the court must invalidate the regulation. ${ }^{88}$ Second, if the language of the statute is unclear, the court should refer to the statute's legislative history and divine Congress's intent. ${ }^{89}$ Third, if neither the text nor the legislative history reveal the meaning of the law, the court should defer to the agency's interpretation. ${ }^{90}$

\footnotetext{
78. See supra note 58.

79. ADMIN. CONFERENCE OF THE U.S., supra note 69, at 36; Asimow, supra note 6, at 563-65.

80. 194 F.2d 329 (D.C. Cir. 1952).

81. Id. at $331-32$.

82. Id. at 335 (Miller, J., dissenting).

83. The dissenting judge suggested that the producers label the wine "Blackberry Wine (Boysen Variety)" but both the Commissioner's representative and the majority rejected this idea. Id. at 336 (Miller, J., dissenting). The quaffer of berry wines must be especially susceptible to misleading labelling.

84. Id. at 332 .

85. Id.

86. E.g. Batterton v. Francis, 432 U.S. 416, 425 n.9 (1977); see also 2 K. Davis, supra note 48,

$\S 7.11$, at 54-57 (agency action that does not come from delegated power cannot bind courts).

87. 467 U.S. 837, reh'g denied, 468 U.S. 1227 (1984).

88. Id. at $859-62$

89. Id. at 862-64.

90. Id. at $864-65$.
} 
This increased deference to legislative rules has been extended to interpretative rules. In General Motors Corp. v. Ruckelshaus, the D.C. Circuit held that an interpretative rule deserves the deference described in Chevron.$^{91}$ Similarly, in Arrow Air v. Dole, the court cited Cheuron and stated that "where, as here, two reasonable interpretations are possible, the agency's view must prevail." agency's interpretations. ${ }^{93}$

In the IRS context, the Supreme Court often defers to Treasury regulations and interpretations. ${ }^{94}$ As it said in United States v. Correll," "Congress has delegated to the Commissioner, not to the courts, the task of prescribing" rules under section 7805 of the Gode. ${ }^{96}$ This policy predates Cheoron by many years; courts have consistently deferred to the expertise of the Commissioner.

Courts also tend to defer to the Commissioner's interpretative rules. In Farmar $v$. United States, ${ }^{97}$ the Court of Claims summarized the treatment of revenue rulings, one type of interpretative rule:

Revenue rulings are not binding on this court. They are not accorded a presumption of correctness but must be analyzed for consistency with the statute. Nevertheless, they are entitled to some consideration and carry some weight, especially when the statutory language is considered ambiguous. This stance is consistent with the general deference accorded an IRS interpretation, as well as the Commissioner's authority to choose between reasonable interpretations. ${ }^{88}$

Courts talk as if IRS interpretative rules are different from legislative regulations, but, given the tradition of deference to the Commissioner, the judicial policy towards both is essentially the same.

91. 742 F.2d 1561, 1566-67 (D.C. Cir. 1984) (en banc), cert. denied, 471 U.S. 1074 (1985).

92. 784 F.2d 1118, 1126 (D.C. Cir. 1986).

93. Arrow Air involved a challenge to the rule itself, not the application; as such, the judgment only permitted the Civil Aeronautics Board to apply its interpretative rule. In $G M$, the EPA sought to require automobile manufacturers to repair all vehicles of a recall class, regardless of age or mileage at the time of the repair. The court permitted the agency to apply its interpretation to General Motors.

94. National Muffler Dealers' Ass'n v. United States, 440 U.S. 472, 476-77 (1979); Bingler v. Johnson, 394 U.S. 741, 749-51 (1969); Commissioner v. South Tex. Lumber Co., 333 U.S. 496, 501 (1948) ("Treasury regulations must be sustained unless unreasonable and plainly inconsistent with the revenue statutes. . ..'); Skidmore v. Swift \& Co., 323 U.S. 134, 140 (1940) (dicta); Fawcus Mach. Co. v. United States, 282 U.S. 375, 378 (1931); Brewster v. Gage, 280 U.S. 327 (1930).

95. 389 U.S. 299 (1967).

96. Id. at 307; see also id. at 305-07 (explaining policy behind deference).

97. 689 F.2d 1017 (Ct. Cl. 1982).

98. Id. at 1024 n.12 (citations omitted). 


\section{G. The Problem of Compelled Taxpayer Deference}

Under section 6661 and its regulations, taxpayers must pay the same deference to IRS interpretative announcements as courts do, or risk a fine for the substantial understatement of tax liability. This destroys the theoretical and appropriate distinction between legislative and interpretative rules.

Treasury Regulation 1.6661-3 includes IRS interpretative rulings, along with the Code, court cases, and legislative rules, as the exclusive forms of permissible authority ${ }^{98}$ The fact that a court may find an interpretative rule substantively correct-or may have a presumption that the IRS's interpretations are correct ${ }^{100}$ - does not mean that interpretative and legislative rules should not be distinguished. ${ }^{\mathbf{1 0 1}}$ Treasury Regulation 1.6661-3(b)(2) equates the authoritative value of interpretative and legislative rules, and thus violates a basic principle of administrative law, i.e. the distinction between interpretative and legislative rules. ${ }^{102}$ Courts continue to characterize interpretative rules as merely the litigating position of agencies; ${ }^{103}$ it would therefore be unfair to require taxpayers to accept these rules as though they were law.

Section 6661, as interpreted by Treasury Regulation 1.6661-3, has this effect. By treating revenue rulings and other interpretative rules as authorities which, if contrary to the taxpayer's position, could negate the "authority" the taxpayer can cite in her favor, Regulation 1.6661-3 threatens to penalize the taxpayer for failing to defer to the IRS's position, which effectively gives it the deterrent power of a law.

In order to escape the substantial understatement penalty, the taxpayer must show more authority than required under the "reasonable basis" standard, but need not meet the level required by a "more likely than not" standard. ${ }^{104}$ The Service will take all recognized authorities into account when evaluating substantial underpayment penalties, and recognizes that "[t]here may be substantial authority for more than one position with respect to the same item."105 When tax shelters are involved, the taxpayer must demonstrate not only that substantial authority exists for her position, but also that she reasonably concluded (either alone or with the help

99. Treas. Reg. $\S 1.6661-3($ b)(2) (1985).

100. Cf. Welch v. Helvering, 290 U.S. 111, 115 (1933) (taxpayer has burden of proof to claim deduction).

101. The framers of the APA believed that interpretative rules would receive more intense scrutiny from courts. See supra note 58.

102. See K. Davis, supra note 48, $\S \S 7.9-.11$, at $43-57$ (using Nazis as example of administrative agencies run riot).

103. See supra notes $94-98$ and accompanying text.

104. Treas. Reg. $\S 1.6661-3($ a)(2) (1985); see also H.R. Conf. REP. No. 760, 97th Cong., 2d Sess. 575 (1982) [hereinafter TEFRA CONFERENCE REPORT], reprinted in 1982 U.S. CoDE CoNG. \& ADMIN. News 1190, 1347 (phrase "substantial authority" used to suggest more than "reasonable basis" but less than "more likely than not").

105. Treas. Reg. § 1.6661-3(b)(1) (1985). 
of a tax advisor) that "there is a greater than 50-percent likelihood that the tax treatment of the item will be upheld in litigation if the claimed treatment is challenged. . ." ${ }^{\text {106 }}$ Moreover, the Regulation declares that "[t]here is substantial authority for the tax treatment of an item only if the weight of the authorities supporting the treatment is substantial in relation to the weight of authorities supporting contrary positions."107

This regulation ignores the proper distinction between legislative and interpretative rules. Neither courts nor the Service should impose substantial understatement penalties solely on the basis of an IRS interpretative rule. Instead, such penalties should be imposed only if the rule has become accepted in judicial precedent or has passed through notice and comment. ${ }^{108}$ Thus, a clear, applicable court precedent or a legislative rule could become preclusive authority ${ }^{109}$ for the section 6661 penalty.

Precedent should be preclusive authority for the purposes of the section 6661 penalty. These norms are legitimate for two principal reasons: First, both sides are involved in the dispute (representation); second, the decisionmaker stands independent of the two litigants (neutrality). Courts can thus transform the litigating position of one party into a legal norm. Under this proposal, a court-either an Article III court or the Tax Court ${ }^{110}$ - could affirm the Commissioner's substantive tax position and use that decision in the future as authority justifying imposition of section 6661 penalties. But imposing the fine on taxpayers solely because they challenge an interpretative rule would in some instances penalize them for advancing colorable positions. ${ }^{111}$ In such cases, the court essentially defers to one party's litigating position-denying neutrality-without the involvement of the adversely affected party-denying representation.

Notice and comment also generates binding norms, with a somewhat different basis for their legitimacy. It permits affected parties to participate in the rulemaking process, thus mirroring some of the values inher-

106. Id. $\S 1.6661-5(\mathrm{~d})$.

107. Id. $\S 1.6661-3(\mathrm{~b})(1)$.

108. One exception to this rule might be letter determinations addressed to the taxpayer. See supra notes 37-39 and accompanying text. These might constitute an exception because the taxpayer requested the ruling. Considering that the IRS can err in its tax advice, this Note does not propose that letter determinations adverse to the named taxpayer be accorded the "preclusive effect", see infra note 109 (defining preclusive effect), of a legislative rule or precedent. Letter determinations in favor of the taxpayer should exculpate her from the substantial understatement penalty in any case.

109. A "preclusive authority" is one that would have a strong presumption of correctness; "preclusive effect" is the effect that a preclusive authority has, i.e. almost outweighing any other authority the taxpayer might cite. The intent is to create a level of deference similar to Arrow Air and General Motors v. Ruckleshaus.

110. The Tax Court is as likely to be neutral as Article III courts. Even though the members of the Tax Court have terms that expire, I.R.C. $\S 7443$ (e) (1986), they are not at the beck and call of the Internal Revenue Service. Only the President may remove Tax Court judges, and then only with cause. I.R.C. $\$ 7443$ (f) (1986).

111. Not all taxpayers who challenge interpretative rules advance colorable positions. Sometimes taxpayers attempt to challenge longstanding, judicially recognized interpretative positions, and should pay the $\S 6661$ penalty. See cases cited supra note 27 . 
ent in democratic decisionmaking. The historical record strongly supports applying the notice and comment requirement to the IRS. Both the work of the Attorney General's Committee on Administrative Procedure and the legislative history of the APA indicate that the promulgation of tax policy was intended to comply with this norm. In its monograph describing the regulatory process of the Bureau of Internal Revenue, the Committee noted that while the Bureau's personnel had the advantages of expertise, they could benefit from the views of affected parties. ${ }^{12}$ While the Committee realized that formal hearings might lengthen the regulations process, ${ }^{113}$ it suggested that the Bureau could publish proposed regulations in the Internal Revenue Bulletin and invite written commentary-processes which mirror the informal rulemaking of the APA in section 553114 - and pointed to the Alcohol Tax Unit as an example of how such consultation could help the Bureau formulate more coherent regulations. ${ }^{115}$

There is also a strong policy behind encouraging notice and comment: It protects due process values and enhances the legitimacy of agency action. As Professor Asimow has written:

Public participation promotes fundamental democratic values by enhancing the responsiveness of agencies to the interest groups affected by regulation. It opens the process to groups and individuals with discordant points of view who might otherwise not have been heard during the agency's routine process of consultation with the public. In short, through advance notice and comment, every constituency has an opportunity to participate in a meaningful manner in making the laws that will affect it. ${ }^{116}$

Notice and comment is not without cost: It can be an expensive procedure that increases the costs of issuing regulations. Some have speculated that if agencies were required to issue interpretative rules with notice and comment, informal, unannounced policies would be pursued in their stead, thus diminishing public knowledge of IRS policy. ${ }^{117}$ It is unlikely, how-

112. U.S. Atrorney Gen.'s Comm. on Admin. Procedure, Monograph No. 22, Administration of Internal Revenue Laws 143-49 (1940) [hereinafter Monograph]. At one point, the Committee differentiated Regulations, which were more formal, and Treasury Decisions, or TDs, which "usually interpret[ed] a particular provision or phase [sic; phrase?] of the law." Id. at 144. One might establish a rough equivalence between the TDs and today's revenue rulings. See supra note 34 and accompanying text (defining revenue rulings).

113. MonograpH, supra note 112 , at 147-48.

114. Compare id. at 148 (proposal to publish proposed regulations and invite commentary) with 5 U.S.C. $\S 553$ (1982) (informal rulemaking through notice and written comment).

115. Monograph, supra note 112 , at 148-49. While recognizing that the Unit dealt with more technical matters and a more contained and sophisticated group of taxpayers, the Committee observed that "the Unit's success in soliciting informed opinions should not be wholly ignored in considering the practicability of the Bureau's outside participation in its rule-making process." Id. at 149 .

116. Asimow, supra note 5 , at 402 .

117. Professor Asimow, id. at 403-04, views notice and comment as an additional cost that dimin- 
ever, that such an extreme reaction would result from the rule proposed in this Note. Since the proposal is limited to the penalties imposed under section 6661, the most the IRS could lose from failing to follow notice and comment is the penalties it might collect from taxpayers who decide to challenge the rule. The public fisc will not lose the actual taxes owed or the interest on the back taxes. ${ }^{118}$

Interpretative rules cannot make the claim for legitimacy that precedent or legislative rules can. They do not promote the values of representation and neutrality that are found in court proceedings, nor do they have the value of participation found in notice and comment. Instead, interpretative rules-although frequently well thought out-are simply the agency's ipse dixit. For that reason, courts have feinted at treating them differently, if only for rhetorical purposes. The proposal in this section attempts to preserve that distinction.

\section{Limitations on Proper Authority}

Even if the proposal suggested above were adopted, the IRS's cabined interpretation of "authority" would still accord it a great deal of leverage over the taxpayer. The IRS has restricted the authorities that a taxpayer may cite in attempting to avoid a section 6661 penalty to include only the Code, court cases, regulations, and "administrative pronouncements (including revenue rulings and revenue procedures)."119 The regulations specifically exclude other sources that taxpayers and courts routinely refer to, including less formal administrative pronouncements, opinions by practitioners, ${ }^{120}$ and conclusions reached in legal periodicals. ${ }^{121}$

This restriction creates problems for taxpayers who end up owing substantive liability but wish to avoid the penalty. The Regulation makes it unlikely that the taxpayer will find recognized support for any position

ishes the production of nonlegislative rules because "a regulatory program can function without them." Id. at 405 (emphasis deleted); see also id. at 404-07 (describing economic model of bureaucratic choice); id. at 408 (applying model to IRS).

118. See supra notes 16-18. In addition, the Tax Reform Act of 1986 corrected many of the substantive loopholes in the Code. Thus, it has controlled some of the loss that might otherwise have resulted. See M. GRAETZ, supra note 13, at 37, 95.

119. Treas. Reg. $\$ 1.6661-3(\mathrm{~b})(2)$ (1985). A taxpayer may also cite Notices and Announcements if they contain specific language permitting reliance. Rev. Rul. 87-138, 1987-2 C.B. 287.

120. Private practitioners' opinion letters have always posed a problem for the IRS. See Falk, Tax Ethics, Legal Ethics, and Real Ethics: A Critique of ABA Formal Opinion 85-352, 39 TAX LAw. 643 (1985) (criticizing ABA standard for opinion letters); Note, Redefining the Attorney's Role in Abusive Tax Shelters, 37 STAN. L. REv. 889 (1985) (attorneys should not be allowed to issue negative opinion letters). The Code now penalizes attorneys and other tax professionals for aiding and abetting understatement of tax liability. I.R.C. $§ 6701$ (1986). To render an opinion letter supporting a tax shelter, an attorney must believe that the taxpayers will more likely than not realize the tax benefits promised in the shelter offering. 31 C.F.R. $\$ 10.33(4)-.33(5)(1988)$. If an attorney could not reasonably believe in this likelihood, the IRS may disbar that attorney from practice before the Service. $I d$. $\S 10.50-.51$.

121. Treas. Reg. § 1.6661-3(b)(2) (1985). 
the IRS has not already endorsed. ${ }^{122}$ The comparison test the Regulation establishes makes it likely that the IRS's sources will overwhelm the sum of authorities that could exculpate the taxpayer, or at least diminish their significance in the total framework of regulations. ${ }^{123}$

When a taxpayer contests a section 6661 penalty, she should be permitted to cite all of the sources upon which she may rely to exculpate herself from substantive liability. ${ }^{124}$ For defense purposes, there is no distinction between between substantive liability and the fine; thus, the limitation has no sound basis. Tax procedure should be seen as analogous to Rule 11 of the Federal Rules of Civil Procedure, which allows a party to make "a good faith argument for the extension, modification, or reversal of existing law. . . "125 Like Rule 11, the suggested amendment of Treasury Regulation 1.6661-3 protects in-court behavior. The proposal still protects the IRS's substantive conclusion; it only allows a taxpayer to defend against the penalty using whatever sources possible so long as that use is in good faith and not abusive.

Another analogy to attorney behavior, one more germane to the tax context, also suggests itself. In its Formal Opinion 85-352, the American Bar Association advised that "a lawyer may advise reporting a position on a return even where the lawyer believes the position probably will not prevail, there is no 'substantial authority' [with reference to section 6661] in support of the position, and there will be no disclosure of the position in the return." ${ }^{128}$ With regard to tax shelter opinions, the American Bar Association has argued that an attorney should be able to question a revenue ruling in a tax shelter opinion letter. ${ }^{127}$ If attorneys can offer advice to third parties on the basis of overturning a revenue ruling, taxpayers should be able to question those rulings without penalty.

122. See supra notes $29-47$ and accompanying text (description of IRS pronouncements); see also cases cited supra note 26 ( $\$ 6661$ penalty not imposed only because Service's factual determinations about taxpayer's transactions were incorrect).

123. This argument presumes that the IRS will not contradict itself within the set of relevant pronouncements. Courts will strike revenue rulings if they are contrary to law, Commissioner v. Engel, 464 U.S. 206, 225-26 (1984) (revenue ruling concerning depletion allowance contrary to law and hence void), but this will only help the taxpayer challenging the revenue ruling if she wins on the substantive tax claim. If the taxpayer loses on that issue, then the substantial understatement penalty may be imposed.

124. For example, a taxpayer could cite a GCM for her position. Even though the Court has said that taxpayers may not rely on GCMs and that Treasury may reverse its own GCMs, Dixon v. United States, 381 U.S. 68 (1965), an uncontradicted GCM should provide some weight to a taxpayer's claim of substantial authority. Similarly, a taxpayer should be able to cite a treatise, article, or student note in support of her position.

125. FED. R. CIv. P. 11. A party need not cite cases to make its good faith argument but can rely on other sources. See Indianapolis Colts v. Mayor of Baltimore, 775 F.2d 177, 184 (7th Cir. 1985) (court exonerates party from Rule 11 sanction because judges had disagreed on merits earlier).

126. ABA Comm. on Ethics and Professional Responsibility, Formal Op. 85-352 (1985), reprinted in 39 TAX LAW. 631 (1985).

127. ABA Comm. on Ethics and Professional Responsibility, Formal Op. $82-346$ (1982), cited in Falk, supra note 120 , at 656 n.54. 


\section{Implementing the Proposals}

These proposals could be effected either by judicial interpretation of section 6661 or through statutory amendment. It is unlikely, however, that a court would reinterpret Treasury Regulation 1.6661-3 in the manner suggested here because of the deference suggested by the Chevron test. ${ }^{128}$ First, the language of section 6661 is ambiguous regarding the exclusion of interpretative rules. Evaluating section 6661 under the second test, congressional intent, some language in the legislative history implies that section 6661 should apply to interpretative rules. ${ }^{129}$ Moreover, even if one treats the legislative history as ambiguous, the Cheuron default treatment for agency regulations is to defer to agency discretion, and therefore the interpretation of "authority" in Treasury Regulation section 1.6661-3(b) would probably be accepted.

All challenges to agency action face increased deference to agency discretion after Chevron. But in the taxation context particularly, a statutory approach may be the only solution. First, the courts have a longstanding tradition of deference to the Commissioner's position. ${ }^{130}$ Second, some courts have interpreted the specific grant of rulemaking authority in section 7805 of the Code as a limit on the application of the APA, ${ }^{131}$ despite the intention of the APA framers to have heightened judicial review for interpretative regulations. ${ }^{132}$

A statutory proposal might also be the more effective solution. When considering the reasonability of tax regulations, courts sometimes rely on a legal fiction embodied in the doctrine of legislative reenactment. In short, the doctrine provides that if an agency issues a regulation and Congress amends any part of the Code-even a section unrelated to the challenged regulation-courts will defer even more to the agency's discretion because Congress could have amended the Code to overrule the agency's regulation. ${ }^{133}$ This doctrine makes heroic assumptions about the efficacy of con-

128. Chevron U.S.A. v. Natural Resources Defense Council, 467 U.S. 837, reh'g denied, 468 U.S. 1227 (1984); see supra notes 88-90 and accompanying text (describing three-part test).

129. See TEFRA Conference Report, supra note 104, at 575, 1982 U.S. Cone Cong. \& ADMIN. News at 1347.

130. See supra notes $94-98$ and accompanying text.

131. See, e.g., Wing v. Commissioner, 81 T.C. 17,30 n.17 (1983).

132. See supra note 58.

133. See Fribourg Navigation Co. v. Commissioner, 383 U.S. 272, 283 (1966) (repeated passage of depreciation provision indicates congressional acceptance of agency interpretations); Lykes $v$. United States, 343 U.S. 118, 126-27, reh'g denied, 344 U.S. 937 (1952) (Congressional amendment of unrelated sections of Code suggests acceptance of all regulations); Helvering v. Winmill, 305 U.S. 79,83 (1938) ("Treasury regulations and interpretations long continued without substantial change, applying to unamended or substantially reënacted statutes, are deemed to have received congressional approval and have the effect of law."); Brewster v. Gage, 280 U.S. 327, 337 (1930) ("The substantial reenactment in later Acts of the provision theretofore construed by the department is persuasive evidence of legislative approval of the regulation."); Eastern Ky. Welfare Rights Org. v. Simon, 506 F.2d 1278,1289 (D.C. Cir. 1974) ("This action or inaction by Congress cannot be interpreted as disapproving the new ruling. Congress could have rejected the ruling had it determined that it was not in conformity with the Code."), vacated on other grounds, 426 U.S. 26 (1975). 
gressional oversight. Usually, when members of Congress pass tax legislation, they do not concern themselves with the entire Code but rather look at specific provisions in the Code to amend. ${ }^{\mathbf{1 3 4}}$ Nevertheless, Congress has amended the Code several times since the enactment of section 6661, and it has amended the Code after the promulgation of the regulations under section $6661 .{ }^{135}$ The precedential impact of the legislative reenactment doctrine might therefore preclude any reinterpretation of "authority" except by Congress.

Despite these obstacles, a court could implement this Note's proposal. Deference under Cheuron applies only if the agency's interpretation is reasonable. ${ }^{138}$ A court could hold that Regulation 1.6661-3 is not reasonable given the background of administrative law and the previously unlimited definition of "authority." A court might also view the Taxpayers' Bill of Rights as a congressional mandate to limit the effect of Treasury regulations. In addition, the legislative history of section 6661 states that Congress intended that "the courts will be free to look at the purpose of this new provision in determining whether substantial authority existed for a position taken in any particular case."137 This suggests that courts, not Treasury, should develop standards of authority. As a predictive matter, however, it is unlikely that a court would adopt the amendments suggested here.

\section{Conclusion}

This Note urges an improvement in the balance between governmental efficiency and governmental responsiveness. The IRS faces the enormous burden of executing, explaining, and, to some extent, determining how the United States government taxes its citizens, but this duty does not create unrestrained power to determine all tax policy. Because the regulations currently ascribe value to the Commissioner's litigating position, taxpayers face fines for questioning the Commissioner's view. The regulations also deny taxpayers the ability to use authorities they might otherwise use to escape substantive liability.

This problem has been created by the increasing amount of deference that courts have paid to administrative agencies over the past decade. As this problem is amplified in the context of section 6661, Congress might, when considering amending that section, also consider limiting the deference courts pay to interpretative rules. A return to the de novo ab initio

134. See, e.g., acts cited supra note 1 . In those acts, Congress amended only portions of the Code. Courts often describe legislative reenactment as a possibility, not a reality. See, e.g., Lykes, 343 U.S. at 126-27; Eastern Kentucky, 506 F.2d at 1289.

135. See supra note 1 and sources cited therein.

136. Chevron U.S.A. v. Natural Resources Defense Council, 467 U.S. 837, 843, reh'g denied, 468 U.S. 1227 (1984).

137. TEFRA CoNfERENCE Report, supra note 104, at 575, 1982 U.S. Code Cong. \& ADMIN. News at 1347 . 
standard of Gibson Wine would hew more closely to the original intent of the APA and would give interpretative rules their proper effect. 